\title{
SERIAL CHANGES IN TISSUE CARBON DIOXIDE CONTENT DURING ACUTE RESPIRATORY ACIDOSIS 1,2
}

\author{
By GEORGE NICHOLS, JR. ${ }^{3,4}$ \\ (From the Departments of Medicine and Biochemistry, Harvard Medical School, Boston, Mass.)
}

(Submitted for publication February 4, 1958; accepted April 17, 1958)

The retention of $\mathrm{CO}_{2}$ in man and animals in chronic respiratory disease and during exposure to atmospheres with high partial pressures of $\mathrm{CO}_{2}$ was first shown a number of years ago (1-4). Its converse, the reduction of $\mathrm{CO}_{2}$ stores during hyperventilation, was demonstrated at the same time. However, considerable doubt has existed as to the site in the body occupied by this store of $\mathrm{CO}_{2}$, how rapidly it equilibrates with blood and alveolar $\mathrm{CO}_{2}$, and what effects its accumulation may have on acid-base equilibria in the extracellular and intracellular compartments.

Brocklehurst and Henderson (1) found small changes in tissue $\mathrm{CO}_{2}$ stores in man in experiments lasting only two to three minutes, while Shaw (2), using cats and a longer equilibration time, postulated that as much as 80 per cent of the $\mathrm{CO}_{2}$ taken up was "buffered" by the tissues. Ferguson, Irving, and Plewes $(3,4)$ attempted to localize the area of storage, but were unable to account for all the $\mathrm{CO}_{2}$ taken up in cats although they found increases in blood, muscle, brain and kidney $\mathrm{CO}_{2}$ content. They pointed out that bone contained 40 to 50 per cent of the total body $\mathrm{CO}_{2}$ and were able to lower bone $\mathrm{CO}_{2} 3$ per cent by hyperventilation, but they failed to raise the bone $\mathrm{CO}_{2}$ content by increasing the $\mathrm{CO}_{2}$ tension in the inspired atmosphere for several hours. More recently, however, Freeman and Fenn found the bone $\mathrm{CO}_{2}$ of rats increased after exposure to 10 per cent $\mathrm{CO}_{2}$ in air for periods of 6 to 28 days (5). They also found considerable increases in muscle $\mathrm{CO}_{2}$. On the other hand, in brief (six hours) hyperventilation experiments with low

\footnotetext{
1 Presented in part at the meeting of the American Physiological Society, Chicago, April, 1957.

2 This work was supported by Research Grants Nos. A-840 and A-840(C) from the National Institute of Arthritis and Metabolic Diseases, United States Public Health Service.

3 Formerly a member of the Howard Hughes Medical Institute.

4 Markle Scholar in Medical Science.
}

oxygen tensions they were not able to mobilize bone $\mathrm{CO}_{2}$ to any appreciable extent. Thus the site of storage of retained $\mathrm{CO}_{2}$, especially in relatively short experiments, has remained in considerable doubt. Furthermore, none of these authors commented to any extent on the changes in acidbase balance which one might expect from such changes in the alveolar $\mathrm{CO}_{2}$ tension and the total $\mathrm{CO}_{2}$ content of the body.

The features of the clinical pattern seen in man with chronic retention of $\mathrm{CO}_{2}$ due to respiratory disease are well known (6), and the chemical findings of this syndrome have been described (7). In this regard, Schaefer (8), studying the possible toxic effects of this gas, has shown that during prolonged exposure of man to 3 to 5 per cent $\mathrm{CO}_{2}$ an adaptive period of respiratory acidosis is followed by a phase of acclimatization during which plasma $\mathrm{pH}$ returns to normal and respiratory stimulation disappears. An increase in the body stores of $\mathrm{CO}_{2}$ during the adaptation to these high $\mathrm{CO}_{2}$ atmospheres was indicated by the large excretion of $\mathrm{CO}_{2}$ by lungs and kidneys during reacclimatization to normal air.

Moreover, a recent series of studies by Schaefer and Nichols (9) of prolonged breath-holding in man during dives to depths of 100 feet (equivalent to an increase in pressure of three atmospheres) have demonstrated that the tissue stores of $\mathrm{CO}_{2}$ can be greatly increased in a very short period of time (two minutes) without any change occurring in the $\mathrm{pH}$ or total $\mathrm{CO}_{2}$ of the plasma. Unfortunately, no data indicating the tissues in which this $\mathrm{CO}_{2}$ was stored could be obtained from these experiments.

The effect of increasing tissue cell $\mathrm{CO}_{2}$ on the acid-base balance of the intracellular space has not been studied extensively. However, Wallace and Hastings (10) and Wallace and Lowry (11) found that the intracellular bicarbonate varied directly with the $\mathrm{CO}_{2}$ tension and not with the bicarbonate ion concentration of the surrounding 
fluids. Thus intracellular $\mathrm{pH}$ varied inversely with extracellular $\mathrm{CO}_{2}$ tension.

The doubts thus raised by others concerning the relation between the duration of exposure and location of $\mathrm{CO}_{2}$ storage and the effects of $\mathrm{CO}_{2}$ storage on the organism led us to re-examine the $\mathrm{CO}_{2}$ contents of several tissues in rats at varying times following the initiation of exposure to an atmosphere containing 24 per cent $\mathrm{CO}_{2}$ in air. The aims of the experiment were to discover where in the body $\mathrm{CO}_{2}$ was stored after various times of exposure and what effect if any this storage might have upon the acid-base balance of the various tissues studied. The data presented below indicate that in the intact rat, exposed for periods up to 48 hours to this atmosphere, the cells of the soft tissues and the extracellular phase were the site of storage of the $\mathrm{CO}_{2}$ retained and were in equilibrium with the alveolar $\mathrm{CO}_{2}$ tension. In contrast, bone mineral $\mathrm{CO}_{2}$ appeared to be in equilibrium with the carbonate ion ${ }^{5}$ concentration in extracellular water rather than with alveolar or extracellular $\mathrm{pCO}_{2}$, and therefore did not serve as a repository for the $\mathrm{CO}_{2}$ accumulated by these animals.

\section{METHODS}

Ninety-three male albino rats weighing 290 to 400 $\mathrm{Gm}$. were used. All rats were at least 120 days old, at which time bone $\mathrm{CO}_{2}$ has stabilized (12). The majority were of the Wistar strain while 10 were of the SpragueDawley strain. No difference between the two strains was found except after 15 hours of exposure to $\mathrm{CO}_{2}$ where the Sprague-Dawley rats seemed to have a higher mortality rate. Eighty-three of the rats were exposed in individual chambers for periods ranging from onehalf to 48 hours to an atmosphere containing 24 per cent $\mathrm{CO}_{2}$ in air. The $\mathrm{CO}_{2}$ content of the atmosphere was checked using the manometric method of Van Slyke (13). At the end of the period of exposure the animals were lightly anesthetized with pentobarbital intraperitoneally and exsanguinated through the abdominal aorta, using oiled syringes and $0.1 \mathrm{ml}$. of sodium heparin to prevent clotting. Samples of muscle, brain and bone were obtained as quickly as possible from the carcass. Exposure to the experimental atmosphere was continued through the period of anesthesia and sacrifice by means of a mask. Ten control rats were sacrificed in the same manner. All animals had access to water and food ad libitum. The rats exposed to high tensions of $\mathrm{CO}_{2}$ ate and drank very little compared to the controls. While

$$
{ }^{5}\left[\mathrm{CO}_{3}^{-}\right]=\mathrm{K}_{2} \frac{\left[\mathrm{HCO}_{3}^{-}\right]}{\left[\mathrm{H}^{+}\right]} \text {where } \mathrm{K}_{2} \text { is the second dissoci- }
$$
ation constant of carbonic acid. this probably had no effect on the composition of the tissues of rats exposed for short periods, it might have produced some differences in those exposed for longer intervals.

The following measurements were made: Whole blood hematocrit was estimated in Wintrobe tubes centrifuged for 30 minutes at $4,000 \mathrm{rpm}$ in an International centrifuge with a no. 240 head. Whole blood $\mathrm{CO}_{2}$ was measured by the manometric method of Van Slyke and Neill (14). $\mathrm{pH}$ was determined at $38^{\circ} \mathrm{C}$. anaerobically using a Beckman glass electrode type 290-31 and a Model G pH meter. Plasma water was measured by a method previously described (17) and plasma chloride in duplicate by the method of Wilson and Ball (15).

Muscle and brain ${ }^{6}$ samples were divided into two parts immediately following excision. One was instantly placed in a tube containing alkaline $\mathrm{FeF}_{3}$ as a metabolic inhibitor and the total $\mathrm{CO}_{2}$ was determined by the method of Danielson and Hastings (16). Muscle, water, fat, and chloride were measured by methods previously described (17). Water and chloride were determined in brain by the same procedures, but no extraction of fat was carried out since such an extraction has been shown to remove electrolyte from this tissue (18).

Bone water and chloride were measured by methods already reported (19). Bone $\mathrm{CO}_{2}$ was determined on the dry powdered bone by a modification of the method of Danielson and Hastings (16). An ash weight was also determined for each bone sample following 48 hours in an electric muffle oven at $550^{\circ} \mathrm{C}$.

Calculations. Plasma total $\mathrm{CO}_{2}$ was determined from the whole blood $\mathrm{CO}_{2}$, the hematocrit, and $\mathrm{pH}$ using Van Slyke and Sendroy's nomogram (20). $\mathrm{pCO}_{2}$ and plasma bicarbonate were calculated from the formulae of Singer and Hastings using a $\mathrm{CO}_{2}$ solubility factor for plasma of 0.0302 and a $\mathrm{pK}$ of 6.10. All calculations were made on the basis of a temperature of $38^{\circ} \mathrm{C}$. Concentrations in plasma water were calculated by the formula previously reported (21).

The total $\mathrm{CO}_{2}$ of fat-free wet muscle was calculated by subtracting the $\mathrm{CO}_{2}$ dissolved in the fat of the muscle sample from the total contained in the sample analyzed. It was assumed that the $\mathrm{pCO}_{2}$ of adipose tissue was the same as plasma. $\mathrm{A} \mathrm{CO}_{2}$ solubility factor for the depot fat of 0.0577 was used (22).

The volume of the extracellular fluid of the tissue samples was assumed to be equal to the chloride space and calculated by the formulae of Hastings and Eichelberger (23). A Donnan distribution factor of 0.98 was used for the calculation of extracellular chloride concentration (24). The volume of intracellular water was obtained by subtracting the extracellular fluid water from the total tissue water. The concentration of $\mathrm{HCO}_{3}^{-}$ in extracellular water was calculated from the values for plasma water divided by a Donnan factor of 0.99 (24), and the carbonic acid of this phase by assuming that the solubility factor for $\mathrm{CO}_{2}$ and the $\mathrm{pCO}_{2}$ in ex-

\footnotetext{
${ }^{6}$ The brain was removed in toto and split longitudinally into two equal parts.
} 
tracellular water were the same as for plasma. Extracellular carbonate $\left(\mathrm{CO}_{3}{ }^{\circ}\right)$ concentration was calculated from the extracellular water $\left(\mathrm{HCO}_{3}^{-}\right)$and the $\mathrm{pH}$ of plasma by the Henderson-Hasselbalch equation using a pK of 9.76 .

In calculating the intracellular concentrations of $\mathrm{H}_{2} \mathrm{CO}_{3}$ and bicarbonate in muscle and brain, the total $\mathrm{CO}_{2}$ contained in the extracellular water was subtracted from the total for the tissue sample. This total intracellular $\mathrm{CO}_{2}$ was then apportioned between $\mathrm{H}_{2} \mathrm{CO}_{3}$ and $\mathrm{HCO}_{3}^{-}$in the following manner. It was assumed that the $\mathrm{PCO}_{2}$ in intracellular fluid was the same as in all other body phases. This was multiplied by a $\mathrm{CO}_{2}$ solubility factor for muscle and brain water of $0.0276^{7}$ to obtain the concentration of $\mathrm{H}_{2} \mathrm{CO}_{3}$. The $\mathrm{H}_{2} \mathrm{CO}_{3}$ was subtracted from the total $\mathrm{CO}_{2}$ to obtain the $\mathrm{HCO}_{3}^{-}$. Finally, intracellular $\mathrm{pH}$ was estimated from the Henderson-Hasselbalch equation using a $\mathrm{pK}$ of 6.10 and assuming no $\mathrm{CO}_{2}$ was bound within the cell.

Bone mineral $\mathrm{CO}_{3}=$ was determined by subtracting the small amount of $\mathrm{CO}_{2}$ contained in the extracellular water of bone from the total $\mathrm{CO}_{2}$ and expressing the remainder in terms of bone ash weight.

\section{RESULTS}

The responses of the individual animals to the atmosphere containing 24 per cent $\mathrm{CO}_{2}$ varied considerably. Some became moribund in a short time, while others after a few hours were able to move about and take food and water. All, however, showed marked hyperpnea and moderate to marked lethargy intermixed with periods of extreme restlessness. This great variability in response was reflected in a large variability from animal to animal in the analytic values for the tissues studied. No significant correlation between the variations of response and the variation in tis-

\footnotetext{
7 This figure represents the average of four determinations carried out on fat-free homogenates of muscle and brain at $\mathrm{pH} 4.01$ and $38^{\circ} \mathrm{C}$. by a method similar to that previously described from this laboratory (22). This value is somewhat lower than that estimated by Danielson, Chu, and Hastings (35) and used in their calculations for the $\mathrm{pK}_{1}$ of carbonic acid in muscle. It was used in these calculations since it represented a direct measurement on the tissues concerned rather than an estimate based on the general effect of proteins on the solubility of $\mathrm{CO}_{2}$ in aqueous solutions. Although lower values for $\mathrm{H}_{2} \mathrm{CO}_{3}$ in all tissues and hence higher $\mathrm{pH}$ 's were obtained thus than would otherwise have been the case and therefore the absolute values for $\mathrm{pH}$ are open to some question, the differences in $\mathrm{pH}$, compared to the controls, which occurred during the experimental periods are not affected.
}

sue analysis could be found. However, despite the considerable differences which occurred from animal to animal, certain trends were uniformly apparent.

Table I presents the means and standard deviations of the means of the analytic values found in plasma, muscle, brain and bone after various periods of exposure to $\mathrm{CO}_{2}$. The figures in parentheses following each mean value indicate the number of individual animals represented by each mean. It can be seen from this table that exposure to 24 per cent $\mathrm{CO}_{2}$ in air produced a prompt profound respiratory acidosis with a marked rise in arterial $\mathrm{pCO}_{2}$ and total plasma $\mathrm{CO}_{2}$. Plasma chloride and water decreased to a smaller extent. These changes were accompanied by a rise in the $\mathrm{CO}_{2}$ content of both muscle and brain, but no apparent change in bone $\mathrm{CO}_{2}$. The other values for tissues showed only minor changes.

Figure 1 presents the plasma values in graphic form and illustrates the degree of acidosis of the extracellular fluids found in these animals after exposure to $\mathrm{CO}_{2}$ for various times. The time scale for the first hour of exposure has been expanded for the sake of clarity in this and subsequent figures. The vertical bars about each point represent one standard deviation on each side of the mean. The $\mathrm{pCO}_{2}$ rose in the first 30 minutes to $180 \mathrm{~mm}$. of mercury. There appeared to be a slight further rise reaching a peak at 15 to 24 hours and a slight decline at 48 hours, but these values are not significantly different from the halfhour value. It is of interest to note that the $\mathrm{pCO}_{2}$ for the arterial plasma (presumably equal to alveolar $\mathrm{pCO}_{2}$ ) appeared higher than that of the inspired air $(180 \mathrm{~mm}$.) from the fifth hour onward. The plasma bicarbonate concentration rose rapidly in the early hours of exposure but not as rapidly as the $\mathrm{pCO}_{2}$. However, as exposure continued, plasma bicarbonate continued to rise at a slow but steady rate although the $\mathrm{pCO}_{2}$ remained relatively stable. The early lag in bicarbonate accretion resulted in a very low $\mathrm{pH}$ after relatively short exposures, while the later rise in bicarbonate without an equivalent increase in $\mathrm{pCO}_{2}$ resulted in some return of $\mathrm{pH}$ toward normal. These changes in plasma values correlate well with the chloride concentrations and are in keeping with the findings of other workers $(25,26)$. They sug- 


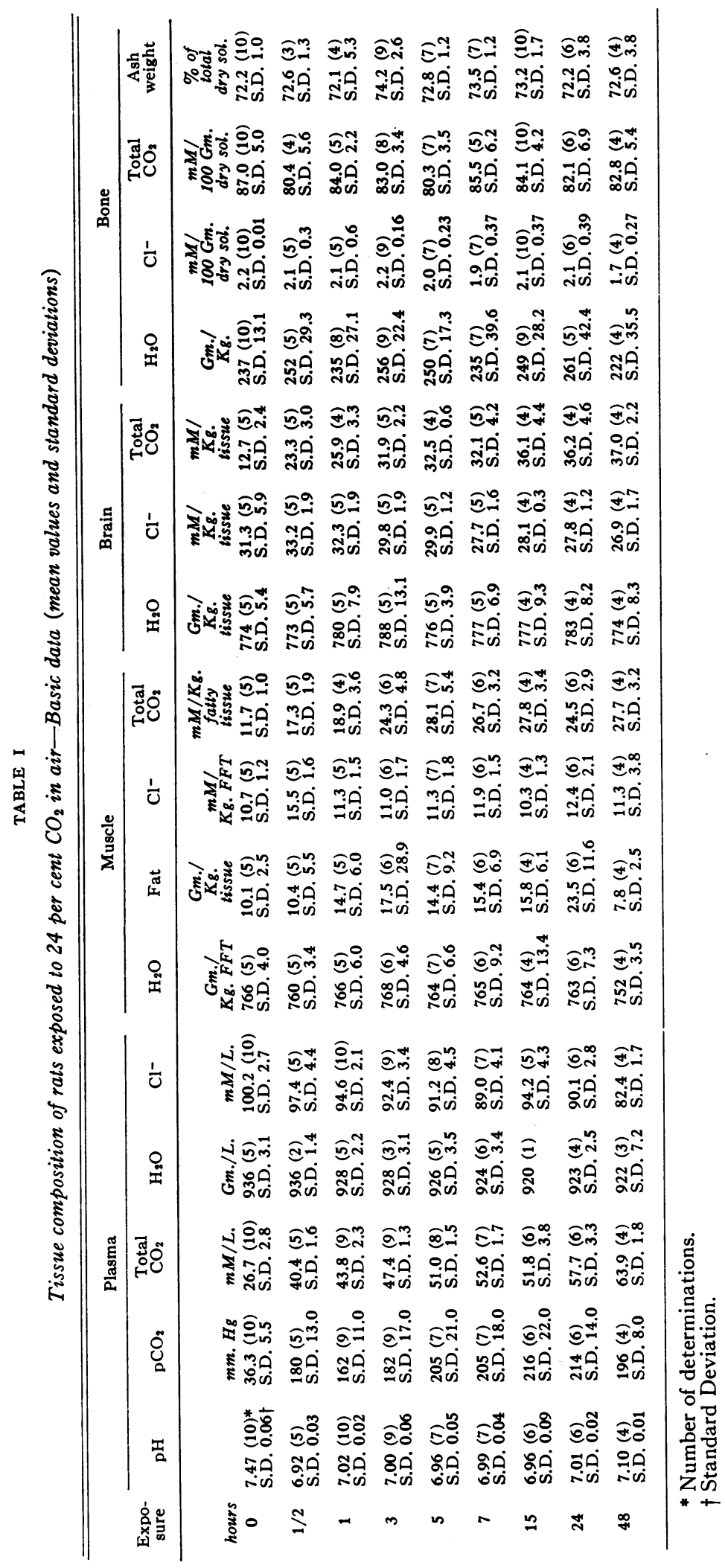




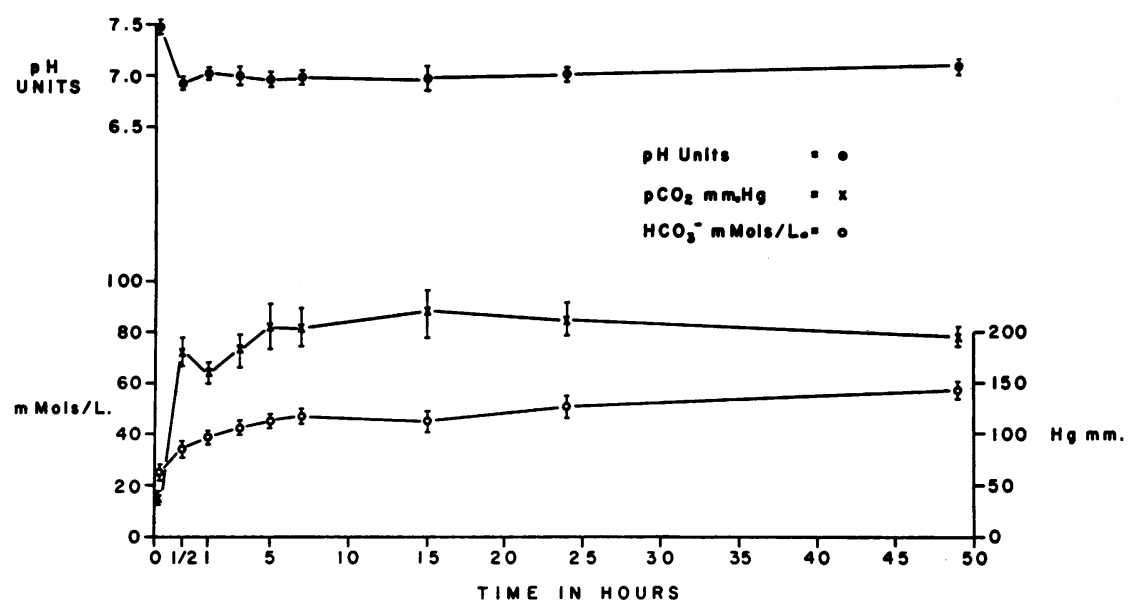

Fig. 1. Plasma Changes During Acute Respiratory Acidosis

gest that our animals, at least by 24 to 48 hours, had passed beyond the phase of acute acidosis and were entering a phase of adaptation to the abnormal atmosphere.

The mean values for total $\mathrm{CO}_{2}$ found in the various tissues are plotted in Figure 2, with the total plasma $\mathrm{CO}_{2}$ included for comparison. The values are expressed in terms of $1 \mathrm{Kg}$. of wet tissue for plasma, brain and for muscle after correction for fat. The accumulation of $\mathrm{CO}_{2}$ in brain and muscle appeared to proceed in a similar fashion, except that the total $\mathrm{CO}_{2}$ content of brain rose more rapidly and reached higher values than was the case in muscle. This difference between the total $\mathrm{CO}_{2}$ of brain and muscle was statistically significant $(p<0.05)$ in six of the eight periods of exposure studied.

With exposures up to five hours the curves of muscle and brain $\mathrm{CO}_{2}$ paralleled the plasma $\mathrm{CO}_{2}$ almost exactly. However, beyond five hours of exposure the total $\mathrm{CO}_{2}$ of these tissues remained stable while plasma $\mathrm{CO}_{2}$ continued to rise slowly. In sharp contrast to the total $\mathrm{CO}_{2}$ of plasma, muscle and brain, the total bone $\mathrm{CO}_{2}$ showed remarkably little change. In fact, there was a decrease in the mean values of bone $\mathrm{CO}_{2}$ of about 7 per cent while the muscle and brain $\mathrm{CO}_{2}$ content rose 140 per cent.

mMOIs/100 Gm. DRY SOLIDS

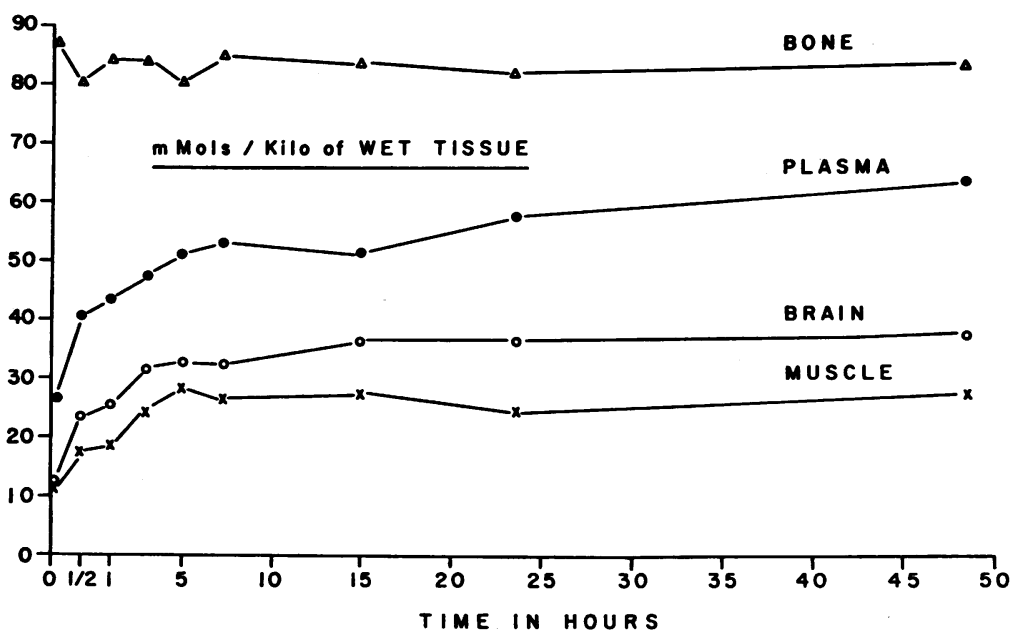

Fig. 2. Distribution of Total $\mathrm{CO}_{2}$ During Acute Respiratory Acidosis 


\section{DISCUSSION}

These data confirm the observations of Schaefer in man (8) that upon exposure to atmospheres rich in $\mathrm{CO}_{2}$ there is an early period of acute respiratory acidosis with hyperpnea, low plasma $\mathrm{pH}$, and lowered urine $\mathrm{pH}$ with decreased urine $\mathrm{HCO}_{3}^{-}$. This is followed by a phase in which the organism has become adapted to the abnormal atmosphere. This adaptive period was characterized in his studies by an increase in $\mathrm{CO}_{2}$ excretion through the lungs, decreased hyperpnea, the appearance of bicarbonate in the urine, and a return of plasma $\mathrm{pH}$ toward normal. From the work of Shaw (2) the inference can be drawn that this adaptive period does not begin until after tissue stores of $\mathrm{CO}_{2}$ have reached an equilibrium with the increased $\mathrm{pCO}_{2}$ of the alveolar air. Our findings for muscle and brain. $\mathrm{CO}_{2}$ conform with this hypothesis since the $\mathrm{CO}_{2}$ content of these two tissues had reached a plateau at five hours, and the adaptive change in plasma $\mathrm{pH}$ did not appear until much later.

A further confirmation might be drawn from the establishment of a plasma $\mathrm{pCO}_{2}$ above that of

TABLE II

Comparison of changes in extracellular water and bone mineral carbonate concentration

\begin{tabular}{|c|c|c|}
\hline Exposure & $\mathrm{CO}_{3}-$ Bone & $\mathrm{CO}_{3}-$ E.C.W. \\
\hline $\begin{array}{c}\text { hrs. } \\
0\end{array}$ & $\begin{array}{c}m M / \text { Kg. mineral } \\
1,185(9)^{*} \\
\text { S.D. } 60 \dagger\end{array}$ & $\begin{array}{l}m M / K g . H_{2} \mathrm{O} \\
0.151(10) \\
\text { S.D. } 0.036\end{array}$ \\
\hline $1 / 2$ & $\begin{array}{l}1,099(4) \\
\text { S.D. } 66\end{array}$ & $\begin{array}{l}0.053(4) \\
\text { S.D. } 0.002\end{array}$ \\
\hline 1 & $\begin{array}{l}1,156(5) \\
\text { S.D. } 60\end{array}$ & $\begin{array}{l}0.074(8) \\
\text { S.D. } 0.006\end{array}$ \\
\hline 3 & $\begin{array}{l}1,109(8) \\
\text { S. D. } 38\end{array}$ & $\begin{array}{l}0.082(9) \\
\text { S. D. } 0.013\end{array}$ \\
\hline 5 & $\begin{array}{l}1,090(7) \\
\text { S.D. } 38\end{array}$ & $\begin{array}{l}0.079(8) \\
\text { S.D. } 0.011\end{array}$ \\
\hline 7 & $\begin{array}{l}1,151(5) \\
\text { S.D. } 81\end{array}$ & $\begin{array}{l}0.086(7) \\
\text { S.D. } 0.010\end{array}$ \\
\hline 15 & $\begin{array}{l}1,138(10) \\
\text { S.D. } 55\end{array}$ & $\begin{array}{l}0.080(6) \\
\text { S.D. } 0.022\end{array}$ \\
\hline 24 & $\begin{array}{l}1,129(6) \\
\text { S.D. } 140\end{array}$ & $\begin{array}{l}0.099(6) \\
\text { S.D. } 0.007\end{array}$ \\
\hline 48 & $\begin{array}{l}1,127(4) \\
\text { S.D. } 68\end{array}$ & $\begin{array}{l}0.139(4) \\
\text { S.D. } 0.002\end{array}$ \\
\hline
\end{tabular}

* Number of determinations.

† S.D., standard deviation. the inspired air after the fifth hour. During the process of "saturation" described by Shaw and seen in the short periods of exposure of our animals, the normal downward gradient of $\mathrm{pCO}_{2}$ from tissue cell to ambient air must be reversed. Under such circumstances the respiratory quotient (R.Q.) would fall to low levels as Shaw has shown. However, once the tissue stores of $\mathrm{CO}_{2}$ have been saturated, some downward gradient of $\mathrm{pCO}_{2}$ from tissue to air must be re-established for the $\mathrm{CO}_{2}$ produced by tissue metabolism to be excreted. The reappearance of such a gradient would produce a return of the R.Q. to normal ranges. This occurred in Shaw's experiments. It should also be evidenced by the appearance of a higher $\mathrm{pCO}_{2}$ in the arterial blood than is found in the inspired air as was demonstrated here.

The bone $\mathrm{CO}_{2}$ values, however, do not fit into this concept that all tissue $\mathrm{CO}_{2}$ stores reach a rapid equilibrium with alveolar $\mathrm{pCO}_{2}$. The apparent discrepancy between the bone $\mathrm{CO}_{2}$ values found after short exposure to $\mathrm{CO}_{2}(3,4)$ compared to prolonged exposure (5) suggested to us that the bone $\mathrm{CO}_{2}$ content was not in equilibrium with alveolar $\mathrm{pCO}_{2}$ in our experiments but rather was related to some other. parameter which changed more slowly during the various stages of adaptation to high $\mathrm{CO}_{2}$ atmospheres.

Underwood, Toribara, and Neuman, studying the $\mathrm{CO}_{2}$ of bone and synthetic apatites with infrared spectroscopy, have shown that bone mineral $\mathrm{CO}_{2}$ is entirely present as $\mathrm{CO}_{3}{ }^{=}$ion (27). They have also shown that the $\mathrm{CO}_{3}=$ content of synthetic apatites varies directly with the $\mathrm{HCO}_{3}^{-}$concentration in the surrounding fluids at constant $\mathrm{pH}$ (28). Evidence is also available that bone $\mathrm{CO}_{2}$ content varies directly with extracellular $\mathrm{pH}$ (29, 30). In metabolic acidosis and alkalosis these two parameters vary in parallel fashion, and, therefore, it is impossible to distinguish the effect of one from the other upon bone carbonate concentration. In respiratory acidosis and alkalosis, however, they vary in opposite directions. Thus, the effect of raising $\mathrm{HCO}_{3}{ }^{-}$concentration might mask that of a decrease in $\mathrm{pH}$ and vice-versa. However, bicarbonate is capable of dissociating a proton to form carbonate ion according to Equation I.

I

$$
\mathrm{HCO}_{3}^{-} \rightleftarrows \mathrm{H}^{+}+\mathrm{CO}_{3}{ }^{-}
$$


$\mathrm{CO}_{3}=$ Concentration/Kg E.C.W.

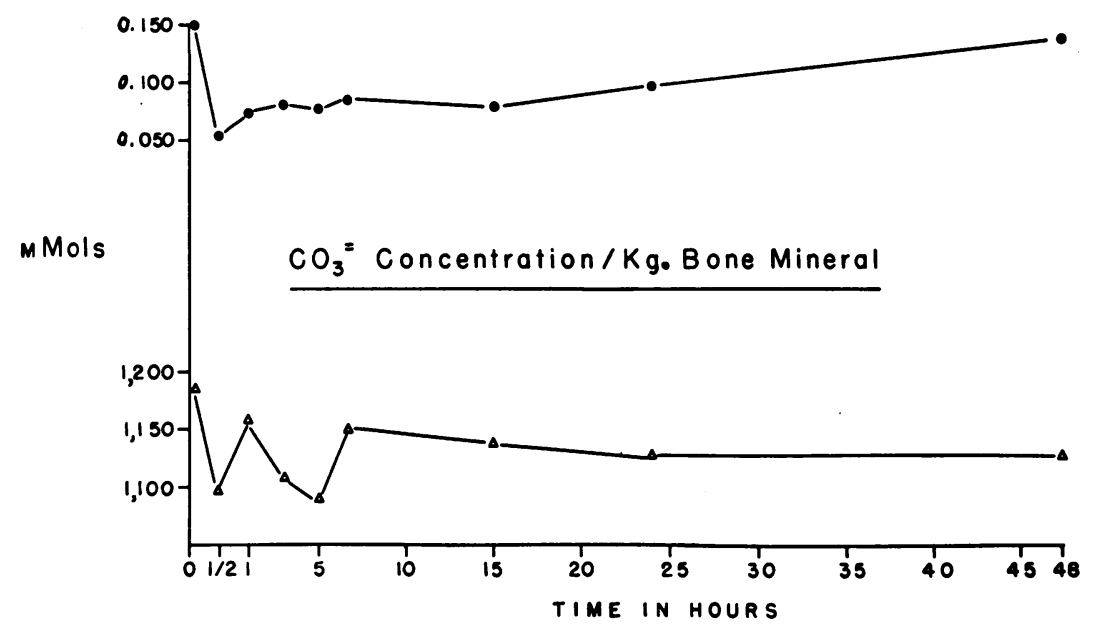

Fig. 3. Distribution of Carbonate (MM per Kg. Extracellular Water) During Acute Respiratory Acidosis

The $\mathrm{pK}$ of this reaction is 9.76 . Thus, by calculating the $\mathrm{CO}_{3}{ }^{=}$ion concentration in extracellular fluid, it is possible to express the effects of variations in both $\mathrm{HCO}_{3}{ }^{-}$and $\mathrm{pH}$ in a single term ${ }^{8}$ and assess their combined actions upon bone $\mathrm{CO}_{2}$ content. Such an expression has the additional appeal of suggesting that bone crystal $\mathrm{CO}_{3}{ }^{=}$is in equilibrium with the $\mathrm{CO}_{3}{ }^{=}$ion concentration in the surrounding fluids, although it is obviously impossible to say whether the proton is dissociated from the bicarbonate in the crystal surface or in the surrounding fluid. In order to examine this proposition the concentrations of carbonate in extracellular water and in bone mineral for each period of exposure were calculated.

The reasons for calculating the bone mineral carbonate concentration were as follows: Of the total amount of $\mathrm{CO}_{2}$ found in bone about 99 per cent is associated with the mineral salts, while only 1 per cent is present as $\mathrm{H}_{2} \mathrm{CO}_{3}$ and $\mathrm{HCO}_{3}^{-}$ in the extracellular fluid of this tissue. Thus, correction of the total bone $\mathrm{CO}_{2}$ for that contained in the extracellular fluid even if that amount was doubled made no significant difference in the final value. However, acidosis has been shown to

8 It is apparent that small changes in $\mathrm{pH}$ will have a relatively greater effect on extracellular water $\mathrm{CO}_{3}=$ concentration than similar changes in $\mathrm{HCO}_{3}^{-}$concentration since the former is an exponential term. cause the release of mineral salts from bone (29, 30 ) and, therefore, values for bone $\mathrm{CO}_{2}$, expressed in terms of the dry solids of bone, might be misleading due to changes in the ratio between organic and mineral solids in certain of the animals.

The results of these calculations are shown in Table II and Figure 3. It can be seen that, despite the marked increase in total $\mathrm{CO}_{2}$ in the plasma (Figure 2), the concentration of $\mathrm{CO}_{3}{ }^{=}$in the extracellular water fell 65 per cent in the first 30 minutes of exposure due to the sharp fall in plasma $\mathrm{pH}$ (Figure 1). It remained at a low level up to 15 hours, then rose slowly as the plasma $\mathrm{pH}$ slowly returned toward normal and the animals entered the phase of adaptation to the abnormal atmosphere. The values of bone mineral carbonate also decrease. This decrease is more rapid in the early hours of exposure, leveling off after 24 hours. No rise is apparent at 48 hours. Unfortunately, the groups of animals exposed for each period were small and the individual variations between animals were very great (see Table II). For these reasons the shape of the bone mineral $\mathrm{CO}_{3}=$ curve is in some doubt, and no precise estimate can be made of the ratio of extracellular $\mathrm{CO}_{3}=$ concentration to bone mineral $\mathrm{CO}_{3}=$ concentration from these data. However, the values for three and five hours of exposure are significantly lower than the controls $(\mathrm{p}<0.02$ and $<0.01$, re- 
TABLE III

Changes in the carbonic acid, bicarbonate, and $p H$ of muscle and brain intracellular water

\begin{tabular}{|c|c|c|c|c|c|c|}
\hline \multirow[b]{2}{*}{ Exposure } & \multicolumn{2}{|c|}{$\mathrm{HCO}_{3}^{-}$} & \multicolumn{2}{|c|}{$\mathrm{H}_{2} \mathrm{CO}_{3}$} & \multicolumn{2}{|c|}{ pH Units } \\
\hline & Muscle & Brain & Muscle & Brain & Muscle & Brain \\
\hline hrs. & \multicolumn{2}{|c|}{$m M / \mathrm{Kg}_{.} \mathrm{H}_{2} \mathrm{O}$} & \multicolumn{2}{|c|}{$m M / K g . ~ H_{2} O$} & & \\
\hline 0 & $\begin{array}{l}12.5(5)^{*} \\
\text { S.D. } 2.0 \dagger\end{array}$ & $\begin{array}{l}10.3(5) \\
\text { S.D. } 2.1\end{array}$ & $\begin{array}{l}1.01(5) \\
\text { S.D. } 0.56\end{array}$ & $\begin{array}{l}1.00(5) \\
\text { S.D. } 0.08\end{array}$ & $\begin{array}{l}7.20(5) \\
\text { S.D. } 0.11\end{array}$ & $\begin{array}{l}7.11(5) \\
\text { S.D. } 0.06\end{array}$ \\
\hline $1 / 2$ & $\begin{array}{l}11.1(5) \\
\text { S.D. } 1.3\end{array}$ & $\begin{array}{l}18.3(4) \\
\text { S.D. 3.8 }\end{array}$ & $\begin{array}{l}4.97(5) \\
\text { S.D. } 0.36\end{array}$ & $\begin{array}{l}4.86(4) \\
\text { S.D. } 0.33\end{array}$ & $\begin{array}{l}6.46(5) \\
\text { S.D. } 0.08\end{array}$ & $\begin{array}{l}6.69(4) \\
\text { S.D. } 0.11\end{array}$ \\
\hline 1 & $\begin{array}{l}16.4(4) \\
\text { S.D. } 5.3\end{array}$ & $\begin{array}{l}19.7(4) \\
\text { S.D. } 8.8\end{array}$ & $\begin{array}{l}4.35(4) \\
\text { S.D. } 0.42\end{array}$ & $\begin{array}{l}4.55(4) \\
\text { S.D. } 0.23\end{array}$ & $\begin{array}{l}6.65(4) \\
\text { S.D. } 0.19\end{array}$ & $\begin{array}{l}6.70(4) \\
\text { S.D. } 0.22\end{array}$ \\
\hline 3 & $\begin{array}{l}23.0(6) \\
\text { S.D. } 7.6\end{array}$ & $\begin{array}{l}29.7(5) \\
\text { S.D. } 5.1\end{array}$ & $\begin{array}{l}4.84(6) \\
\text { S.D. } 0.19\end{array}$ & $\begin{array}{l}5.10(5) \\
\text { S.D. } 0.53\end{array}$ & $\begin{array}{l}6.77(6) \\
\text { S.D. } 0.14\end{array}$ & $\begin{array}{l}6.86(5) \\
\text { S.D. } 0.09\end{array}$ \\
\hline 5 & $\begin{array}{l}26.1(7) \\
\text { S.D. } 8.8\end{array}$ & $\begin{array}{l}27.1(4) \\
\text { S.D. } 1.8\end{array}$ & $\begin{array}{l}5.66(7) \\
\text { S.D. } 0.57\end{array}$ & $\begin{array}{l}5.92(4) \\
\text { S.D. } 0.72\end{array}$ & $\begin{array}{l}6.75(7) \\
\text { S.D. } 0.14\end{array}$ & $\begin{array}{l}6.77(4) \\
\text { S.D. } 0.05\end{array}$ \\
\hline 7 & $\begin{array}{l}24.0(6) \\
\text { S.D. } 5.6\end{array}$ & $\begin{array}{l}26.9(5) \\
\text { S.D. } 8.7\end{array}$ & $\begin{array}{l}5.75(6) \\
\text { S.D. } 0.50\end{array}$ & $\begin{array}{l}5.67(5) \\
\text { S.D. } 0.65\end{array}$ & $\begin{array}{l}6.72(6) \\
\text { S.D. } 0.12\end{array}$ & $\begin{array}{l}6.76(5) \\
\text { S. D. } 0.16\end{array}$ \\
\hline 15 & $\begin{array}{l}27.2(4) \\
\text { S.D. } 4.9\end{array}$ & $\begin{array}{l}34.9(4) \\
\text { S.D. } 8.0\end{array}$ & $\begin{array}{l}5.61(4) \\
\text { S.D. } 0.24\end{array}$ & $\begin{array}{l}7.10(4) \\
\text { S.D. } 0.7\end{array}$ & $\begin{array}{l}6.78(4) \\
\text { S.D. } 0.07\end{array}$ & $\begin{array}{l}6.78(4) \\
\text { S.D. } 0.12\end{array}$ \\
\hline 24 & $\begin{array}{l}20.0(6) \\
\text { S.D. } 4.9\end{array}$ & $\begin{array}{l}30.6(4) \\
\text { S.D. } 7.5\end{array}$ & $\begin{array}{l}5.92(6) \\
\text { S.D. } 0.39\end{array}$ & $\begin{array}{l}6.05(4) \\
\text { S.D. } 0.35\end{array}$ & $\begin{array}{l}6.62(6) \\
\text { S.D. } 0.11\end{array}$ & $\begin{array}{l}6.80(4) \\
\text { S.D. } 0.09\end{array}$ \\
\hline 48 & $\begin{array}{l}24.5(4) \\
\text { S.D. } 6.4\end{array}$ & $\begin{array}{l}28.9(4) \\
\text { S.D. } 2.9\end{array}$ & $\begin{array}{l}5.42(4) \\
\text { S.D. } 0.31\end{array}$ & $\begin{array}{l}5.42(4) \\
\text { S.D. } 0.31\end{array}$ & $\begin{array}{l}6.74(4) \\
\text { S.D. } 0.14\end{array}$ & $\begin{array}{l}6.83(4) \\
\text { S.D. } 0.04\end{array}$ \\
\hline
\end{tabular}

* Number of determinations.

† S.D., standard deviation.

spectively). Furthermore, when the mean value for all the experimental animals is compared to the mean of the controls, it appears to be significantly lower $(p=0.02)$. These data suggest that the bone mineral carbonate in vivo is in equilibrium with the carbonate ion concentration of the extracellular fluids, as postulated above, rather than with the alveolar $\mathrm{CO}_{2}$ tension or the total $\mathrm{CO}_{2}$ of the plasma.

Such an hypothesis offers an explanation for the divergence between the total bone $\mathrm{CO}_{2}$ levels seen in short-term experiments such as are presented here and long-term exposures to atmospheres high in $\mathrm{CO}_{2}$. Thus, after the 6 to 28 days of exposure to 10 per cent $\mathrm{CO}_{2}$ in air required by Freeman and Fenn's (5) animals to show rises in bone $\mathrm{CO}_{2}$, adaptation should have been quite complete with high plasma bicarbonate concentrations and $\mathrm{pH}$ values approaching the normal range. Under such circumstances extracellular $\mathrm{CO}_{3}{ }^{=}$concentration would be elevated and thus bone $\mathrm{CO}_{3}{ }^{=}$ should be similarly increased.

The results of these authors' experiments with rats in which hyperventilation was induced by low $\mathrm{O}_{2}$ tensions also fit this postulation. Following hyperventilation of only six hours, total bone $\mathrm{CO}_{2}$ did not change, while in long experiments ( 11 to 31 days) bone $\mathrm{CO}_{2}$ decreased appreciably. Although no $\mathrm{pH}$ values for plasma are reported, one would expect alkalosis with a high $\mathrm{pH}$ as well as a lower extracellular $\mathrm{HCO}_{3}{ }^{-}$concentration in the six hour animals and thus little change in extracellular $\mathrm{CO}_{3}=$ concentration. In the latter experiments adaptation may well have occurred so that the $\mathrm{pH}$ of the extracellular fluid was approximately normal. If this assumption is correct, the observed reduction in extracellular bicarbonate was accompanied by a reduction of $\mathrm{CO}_{3}=$ concentration and therefore a decrease in bone $\mathrm{CO}_{3}=$.

The apparent failure of bone $\mathrm{CO}_{3}=$ concentration to rise with the plasma $\mathrm{CO}_{3}=$ concentration in the last two experimental periods cannot be explained from the data presented here. One can only speculate whether this is merely an artifact due to wide variations in values and small groups of animals or whether there is some delay of 


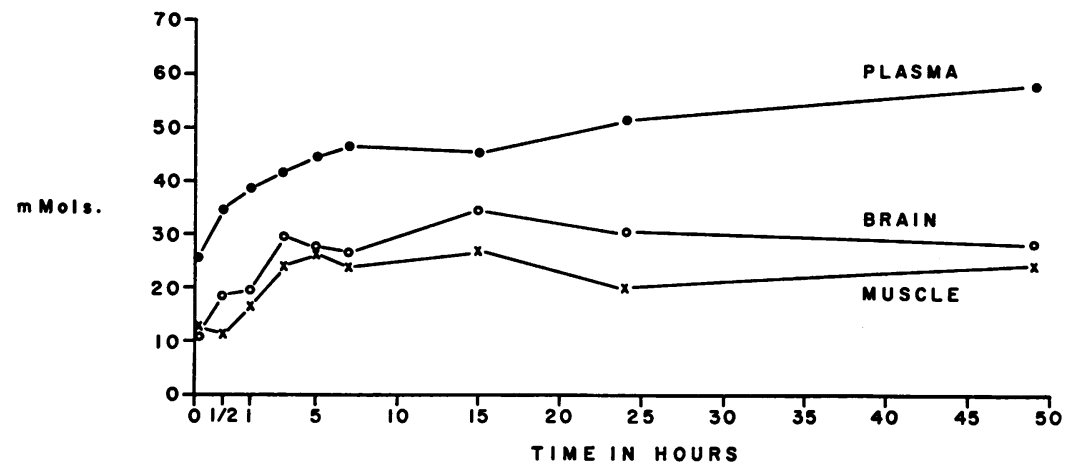

Fig. 4. Distribution of Bicarbonate (MM per Kg. Extracellular Water) During Acute Respiratory Acidosis

equilibration due to slow diffusion in the relatively poorly vascularized bone. It is also possible that some local change may have occurred in the bone itself which influenced the $\mathrm{CO}_{3}{ }^{=}$ion distribution between mineral and extracellular fluid. Further work will be needed to answer these questions.

The increases in $\mathrm{CO}_{2}$ content of muscle and brain presented in Table $I$ and Figures 1 and 2 are considerable. Although the increases in extracellular fluid $\mathrm{CO}_{2}$ content of these animals was large, the total increases in $\mathrm{CO}_{2}$ in these tissue samples could not be accounted for on the basis of changes in the extracellular concentration alone unless the extracellular volumes of the samples obtained were severalfold those usually found (17). Therefore, it was apparent that the intracellular $\mathrm{CO}_{2}$ content must have changed. In order to evaluate these changes and examine what effect storage of $\mathrm{CO}_{2}$ might have had on the acidbase balance of these two tissues, the concentrations of bicarbonate, carbonic acid, and hydrogen ion in the intracellular water of both muscle and brain were calculated for each animal. The averages of the results obtained are presented in Table III and have been plotted graphically in Figures 4 and 5 for comparison with the plasma. It can be seen in Figure 4 that the bicarbonate ion concentration in both brain cells and muscle fibers increased rapidly, reaching a plateau after only three hours of exposure. The accumulation of bicarbonate in the cells of these tissues was considerably more rapid than the accumulation in the plasma since the latter did not reach the slower phase of its accumulation until after seven hours. However, once the cells had accumulated bicarbonate, their stores of this ion remained relatively fixed and if anything tended to decrease slightly with prolonged exposure. Bicarbonate accumulated in both these cell types in a very similar fashion except for the first 30 minutes of exposure. While brain cell bicarbonate almost doubled during this period, muscle fiber bicarbonate did not

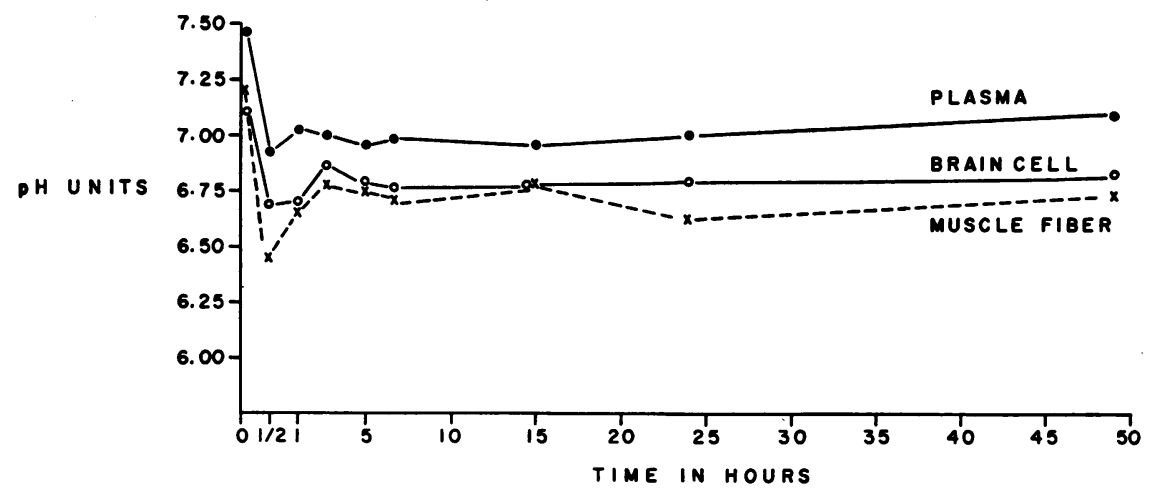

Fig. 5. Comparison of Calculated pH of Muscle Fibers and Brain Cells with Plasma PH 
change, the sharp rise in $\mathrm{HCO}_{3}^{-}$in the latter tissue cell occurring between 30 and 60 minutes. The probability of this difference in response between the two types of cell occurring by chance was only 1 per cent $(p=0.01)$.

Although muscle intracellular bicarbonate concentrations rose more slowly than did those of brain and did not appear to reach as high levels, there was no significant difference between the two tissues except at 30 minutes of exposure. This is in contrast to the values for total tissue $\mathrm{CO}_{2}$ shown in Figure 2. The difference in statistical significance between the two forms of expression lies in the correction made for extracellular fluid $\mathrm{CO}_{2}$. The extracellular volumes found in brain were larger than in muscle and thus the fraction of the total $\mathrm{CO}_{2}$ assigned to the extracellular fluid in this tissue was not only larger but tended to increase more rapidly than in muscle due to the rising extracellular fluid bicarbonate concentration in the longer exposure periods.

These findings are compatible with the concept that the cell membranes of these two tissues are relatively impermeable to bicarbonate ion but freely permeable to $\mathrm{CO}_{2}$ since the ratio of extracellular to intracellular bicarbonate varies both with the tissue and with time. Assuming as we have that the $\mathrm{pCO}_{2}$ is the same at all times in all body phases and having found that the solubility coefficient for $\mathrm{CO}_{2}$ in brain and muscle cell water is the same, then the rate of accumulation of bicarbonate in these cells will depend on the rate at which $\mathrm{CO}_{2}$ becomes hydrated to form $\mathrm{H}_{2} \mathrm{CO}_{3}$, which in turn dissociates to give bicarbonate ion. The enzyme carbonic anhydrase is known to accelerate the hydration of $\mathrm{CO}_{2}$. Since this enzyme is present in appreciable quantities in brain (31) but is virtually absent from muscle, the slower rise of bicarbonate in this tissue may be, in part at least, due to a lack of this enzyme. Further experiments are needed to prove such an hypothesis which can only be suggested from these data.

The changes in the calculated intracellular $\mathrm{pH}$ of muscle and brain may be compared to plasma in Figure 5. The $\mathrm{pH}$ of both these cells falls precipitously in the first 30 minutes, as does the plasma $\mathrm{pH}$. The fall in muscle cells is much greater, however, than that seen in either brain or plasma. After one hour the muscle cell $\mathrm{pH}$ had risen again to the same level as that of brain cells. From then on both remained relatively constant at a level considerably below the controls. The constancy of the $\mathrm{pH}$ of these cells even after 48 hours of exposure may be contrasted to the slow rise in plasma $\mathrm{pH}$ which seems to occur over similar periods during which the animals are showing evidence of adaptation to the $\mathrm{CO}_{2}$ load.

Calculations such as these of the intracellular bicarbonate, carbonic acid, and hydrogen ion concentrations are subject not only to the possible errors involved in the use of a chloride space (17) ${ }^{9}$ but also those inherent in the assumption that the $\mathrm{pCO}_{2}$ of all body phases is the same as that in the alveolus at all times. Although the rate of diffusion of $\mathrm{CO}_{2}$ is not infinitely great, as implied by this assumption, it is known to be rapid and, therefore, whatever differences in $\mathrm{CO}_{2}$ tension existed between the alveoli and the tissue cells at various periods of exposure were probably not large.

We have also assumed, as did Wallace, Hastings, and Lowry $(10,11)$, that no $\mathrm{CO}_{2}$ was bound intracellularly. This view has been challenged by Conway and Fearon (33). However, at the level of $\mathrm{pH}$ ascribed to intracellular water by either Wallace and associates or Conway and Fearon, the amount of $\mathrm{CO}_{2}$ bound as carbamate should be small (34). The binding of $\mathrm{CO}_{2}$ in some other form is certainly suggested by Conway's experiments, but as yet no information is available concerning either the nature of such binding or the factors which might influence it. In this regard, the first $\mathrm{pK}$ for carbonic acid determined for muscle by Danielson, Chu, and Hastings (35) is identical to that of plasma in which little bound $\mathrm{CO}_{2}$ exists. Were significant amounts of $\mathrm{CO}_{2}$ bound by the usual intracellular contents, the $\mathrm{pK}$ calculated from their observations on muscle brei should have been higher.

Although the absolute values of intracellular bicarbonate and $\mathrm{pH}$ presented here are therefore open to question (as outlined above), they give some idea of changes in tissues which occurred during the development of respiratory acidosis. It would appear that stores of $\mathrm{CO}_{2}$ accumulated much more rapidly in the tissue cells than in the extracellular fluid. This rapid accumulation was

${ }^{9}$ This is especially true in the case of brain (32). 
accompanied by the same profound fall in $\mathrm{pH}$ and marked acidosis as was seen in the plasma. Thus, during the early hours of exposure to high $\mathrm{CO}_{2}$ tensions a comparable degree of acidosis existed in plasma and tissues. However, in the latter hours of exposure the adaptative changes which were seen in the plasma did not appear to occur in the tissue cells. No further rise in bicarbonate took place and the $\mathrm{pH}$ remained fixed at a low level. The persistence of some degree of intracellular acidosis, despite the return of plasma $\mathrm{pH}$ to normal, in individuals adapted to atmospheres with increased $\mathrm{CO}_{2}$ tensions, which is suggested by these findings, might be one cause of the impaired cerebral cortical functions described by Schaefer after prolonged exposure to 3 per cent $\mathrm{CO}_{2}(8)$ and seen in chronic respiratory disease $(6,7)$, the changes in the response of the respiratory and vasomotor centers seen in such individuals, and the decrease in the general metabolic rate of man (8) which has been described under these conditions. The proof of this hypothesis must await further work in which measurements of function and the results of direct tissue analysis are compared in the same animal.

\section{SUM MARY}

1. Eighty-three male albino rats were exposed to 24 per cent $\mathrm{CO}_{2}$ in air for periods ranging from one-half to 48 hours, and the $\mathrm{pH}$ and $\mathrm{CO}_{2}$ content of their blood and tissues was compared with control rats.

2. A profound respiratory acidosis with high plasma $\mathrm{CO}_{2}$ and a plasma $\mathrm{pH}$ of 6.92 appeared after one-half hour of exposure. This was followed after 7 to 15 hours by a further slow rise in plasma $\mathrm{CO}_{2}$ and a rising $\mathrm{pH}$ which reached 7.10 after 48 hours.

3. The total $\mathrm{CO}_{2}$ of muscle and brain rose rapidly but reached a plateau after five hours. The rate of rise and the absolute level of tissue $\mathrm{CO}_{2}$ was higher in brain than in muscle. Bone $\mathrm{CO}_{2}$ content in contrast to the other tissues remained fixed or declined slightly even after 48 hours of exposure.

4. It was concluded from these data that the soft tissues rather than the bone formed the site of storage of $\mathrm{CO}_{2}$ under the conditions of these experiments.
5. These findings suggest that the bone $\mathrm{CO}_{2}$ may be in equilibrium with the carbonate ion concentration $\left(\mathrm{CO}_{3}{ }^{\circ}\right)$ of the extracellular fluid rather than with the alveolar $\mathrm{CO}_{2}$ tension as is the case in the soft tissues.

6. Calculations of intracellular $\mathrm{pH}$ and bicarbonate concentration in brain and muscle indicated that a profound acidosis developed rapidly in both these tissues. However, in contrast to plasma no evidence of adaptation with return of $\mathrm{pH}$ toward normal was observed up to 48 hours of exposure. The possible implications of such a persistent intracellular acidosis in the syndrome of adaptation to $\mathrm{CO}_{2}$ retention are discussed.

\section{ACKNOWLEDGMENTS}

The author is deeply indebted to Dr. Nancy Nichols for encouragement and critique during the course of the whole study and for invaluable assistance with the preparation of a number of the later animals and the analysis of their tissues. The technical assistance of Miss Joan Button is gratefully acknowledged.

\section{REFERENCES}

1. Brocklehurst, R. J., and Henderson, Y. The buffering of the tissues as indicated by the $\mathrm{CO}_{2}$ capacity of the body. J. biol. Chem. 1927, 72, 665 .

2. Shaw, L. A. The comparative capacity of the blood and of the tissue to absorb carbonic acid. Amer. J. Physiol. 1926-27, 79, 91.

3. Ferguson, J. K. W., Irving, L., and Plewes, F. B. The source of expired $\mathrm{CO}_{2}$ in decapitated, eviscerated cats. J. Physiol. 1929-30, 68, 265.

4. Irving, L., Ferguson, J. K. W., and Plewes, F. B. The source of $\mathrm{CO}_{2}$ expired and the site of its retention. J. Physiol. 1930, 69, 113.

5. Freeman, F. H., and Fenn, W. O. Changes in carbon dioxide stores of rats due to atmospheres low in oxygen or high in carbon dioxide. Amer. J. Physiol. 1953, 174, 422.

6. Dickens, C. Posthumous Papers of the Pickwick Club. London, Chapman and Hall, 1836, chap. IV.

7. Burwell, C. S., Robin, E. D., Whaley, R. D., and Bickelmann, A. G. Extreme obesity associated with alveolar hypoventilation, a Pickwickian syndrome. Amer. J. Med. 1956, 21, 811.

8. Schaefer, K. E. Studies of Carbon Dioxide Toxicity (1.) Chronic $\mathrm{CO}_{2}$ Toxicity in Submarine Medicine. U. S. Naval Medical Research Laboratory Report No. 181, 1951, vol. 10, p. 156.

9. Schaefer, K. E., and Nichols, G., Jr. Unpublished observations.

10. Wallace, W. M., and Hastings, A. B. The distribution of the bicarbonate ion in mammalian muscle. J. biol. Chem. 1942, 144, 637. 
11. Wallace, W. M., and Lowry, O. H. An in vitro study of carbon dioxide equilibria in mammalian muscle. J. biol. Chem. 1942, 144, 651.

12. Kramer, B., and Shear, M. J. Composition of bone. IV. Primary calcification. J. biol. Chem. 1928, 79, 147.

13. Peters, J. P., and Van Slyke, D. D. Quantitative Clinical Chemistry, Vol. II, Methods. Baltimore, Williams and Wilkins, 1932.

14. Van Slyke, D. D., and Neill, J. M. The determination of gases in blood and other solutions by vacuum extraction and manometric measurement. J. biol. Chem. 1924, 61, 523.

15. Wilson, D. G., and Ball, E. G. A study of the estimation of chloride in blood and serum. J. biol. Chem. 1928, 79, 221.

16. Danielson, I. S., and Hastings, A. B. A method for determining tissue carbon dioxide. J. biol. Chem. 1939, 130, 349.

17. Nichols, G., Jr., Nichols, N., Weil, W. B., and Wallace, W. M. The direct measurement of the extracellular phase of tissues. J. clin. Invest. 1953, 32, 1299.

18. Eichelberger, L., and Richter, R. B. Water, nitrogen, and electrolyte concentration in brain. J. biol. Chem. 1944, 154, 21.

19. Nichols, G., Jr., and Nichols, N. Changes in tissue composition during acute sodium depletion. Amer. J. Physiol. 1956, 186, 383.

20. Van Slyke, D. D., and Sendroy, J., Jr. Studies of gas and electrolyte equilibria in blood. XV. Line charts for graphic calculations by the HendersonHasselbalch equation, and for calculating plasma carbon dioxide content from whole blood content. J. biol. Chem. 1928, 79, 781.

21. Nichols, G., Jr., and Nichols, N. Electrolyte equilibria in erythrocytes during diabetic acidosis. J. clin. Invest. 1953, 32, 113.

22. Nichols, G., Jr. The solubility of carbon dioxide in body fat. Science 1957, 126, 1244.
23. Hastings, A. B., and Eichelberger, L. The exchange of salt and water between muscle and blood. I. The effect of an increase in total body water produced by the intravenous injection of isotonic salt solutions. J. biol. Chem. 1937, 117, 73.

24. Manery, J. F. Water and electrolyte metabolism. Physiol. Rev. 1954, 34, 334.

25. Cooke, R. E., Coughlin, F. R., Jr., and Segar, W. E. Muscle composition in respiratory acidosis. J. clin. Invest. 1952, 31, 1006.

26. Miller, A. T., Jr. Acclimatization to carbon dioxide: A study of chemical and cellular changes in the blood. Amer. J. Physiol. 1940, 129, 524.

27. Underwood, A. L., Toribara, T. Y., and Neuman, W. F. An infrared study of the nature of bone carbonate. J. Amer. chem. Soc. 1955, 77, 317.

28. Neuman, W. F., Toribara, T. Y., and Mulryan, B. J. The surface chemistry of bone. IX. Carbonate: phosphate exchange. J. Amer. chem. Soc. 1956, 78, 4263.

29. Goto, K. Mineral metabolism in experimental acidosis. J. biol. Chem. 1918, 36, 355.

30. Irving, L., and Chute, A. L. The participation of the carbonates of bone in the neutralization of ingested acid. J. cell. comp. Physiol. 1932, 2, 157.

31. Ashby, W. Carbonic anhydrase as a factor in the organization of the central nervous system. J. nerv. ment. Dis. 1951, 114, 391.

32. Koch, A., and Woodbury, D. M. Kinetics of cellular action of injected bicarbonate in cerebral cortex. Fed. Proc. 1957, 16, Part I, 313.

33. Conway, E. J., and Fearon, P. J. The acid-labile $\mathrm{CO}_{2}$ in mammalian muscle and the $\mathrm{pH}$ of the muscle fibre. J. Physiol. 1944, 103, 274.

34. Meldrum, N. U., and Roughton, F. J. W. The state of carbon dioxide in blood. J. Physiol. 1933, 80, 143.

35. Danielson, I. S., Chu, H. I., and Hastings, A. B. The $\mathrm{pK}_{1}^{\prime}$ of carbonic acid in concentrated protein solutions and muscle. J. biol. Chem. 1939, 131, 243. 